\title{
Neural correlations in the electrosensory lateral line lobe of the weakly electric fish, Apteronotus leptorhynchus: analysis of multi-channel recordings
}

\author{
Teerawat Monnor $^{1 *}$, Michael G Metzen ${ }^{1}$, Maurice J Chacron ${ }^{1,2}$ \\ From The Twenty Third Annual Computational Neuroscience Meeting: CNS*2014 \\ Québec City, Canada. 26-31 July 2014
}

It is recognized that perception and behavior result from the activities of large neural ensembles. As such, it is key to understand the mechanisms that give rise to correlated activity in the brain. However, correlated activity is highly plastic as it is regulated during specific behavioral contexts. In this work, we aim to understand how activation of neural circuits can shape correlated activity by using the weakly electric fish, Apteronotus leptorhynchus. We performed multi-channel recordings in the electrosensory lateral line lobe, which benefits from well-characterized neural architecture. First, a spike-sorting algorithm was applied on the recorded signals to extract neural units. Then, correlated activity can be examined from pairwise population-averaged cross-correlograms calculated from all pairs of the extracted units. We found that the activities are positively correlated for neurons of the same type (ONON, OFF-OFF), but negatively correlated for neurons of opposite type (i.e. ON-OFF). Also, the effect of different stimulus characteristics on the correlation is observed. While the correlation is decreased by conspecific-like stimuli, it is increased by prey-like stimuli. Furthermore, some neurons tend to fire synchronously at particular portions of stimulus, e.g. at specific phases of sinusoidal stimuli. Thus, this work will give important insights in how correlated activity contributes to the processing of natural stimuli.

\section{Authors' details}

'Department of Physiology, McGill University, Montreal, QC, H3G 1Y6, Canada. ${ }^{2}$ Department of Physics, McGill University, Montreal, QC, H3G 1Y6, Canada.

'Department of Physiology, McGill University, Montreal, QC, H3G 1Y6, Canada

Full list of author information is available at the end of the article
Published: 21 July 2014

doi:10.1186/1471-2202-15-S1-P190

Cite this article as: Monnor et al: Neural correlations in the electrosensory lateral line lobe of the weakly electric fish, Apteronotus leptorhynchus: analysis of multi-channel recordings. BMC Neuroscience 2014 15(Suppl 1):P190.
Submit your next manuscript to BioMed Central and take full advantage of:

- Convenient online submission

- Thorough peer review

- No space constraints or color figure charges

- Immediate publication on acceptance

- Inclusion in PubMed, CAS, Scopus and Google Scholar

- Research which is freely available for redistribution

Submit your manuscript at www.biomedcentral.com/submit
C Biomed Central 